\title{
Pemodelan dan Analisa Energi Listrik Yang Dihasilkan Mekanisme Pembangkit Listrik Tenaga Gelombang Air (PLTG-AIR) Tipe Pelampung Silinder Dengan Cantilever Piezoelectric
}

\author{
Sherly Octavia Saraswati dan Wiwiek Hendrowati \\ Jurusan Teknik Mesin, Fakultas Teknologi Industri, Institut Teknologi Sepuluh Nopember (ITS) \\ J1. Arief Rahman Hakim, Surabaya 60111 Indonesia \\ e-mail:wiwiek@me.its.ac.id
}

\begin{abstract}
Abstrak - Gelombang laut merupakan pergerakan naik dan turunnya muka air laut yang membentuk lembah dan bukit. Pemanfaatan energi gelombang laut untuk sumber energi alternatif sangat cocok diterapkan di Indonesia, dimana luas lautannya mencapai 2/3 dari keseluruhan luas Indonesia. Salah satu cara memanfaatkan energi gelombang laut adalah untuk menghasilkan listrik, atau yang biasa disebut pembangkit listrik tenaga gelombang laut (PLTGL). Pada penelitian ini dibuat simulasi mekanisme PLTG-Air tipe pelampung silinder dengan cantilever piezoelectric sebagai pengkonversi energi mekanik dari gearbox menjadi energi listrik, dimana penelitian yang dilakukan menggunakan skala labolatorium. Cantilever piezoelectric material merupakan material yang memiliki kemampuan untuk membangkitkan potensial listrik sebagai respon dari tegangan mekanik yang diberikan pada material tersebut. Blade dipasang pada poros keluaran dari gearbox. Blade inilah yang memukul cantilever piezoelectric hingga mengalami defleksi. Defleksi dari cantilever piezoelectric menimbulkan voltase atau energi listrik. Variasi yang digunakan yang digunakan dalam penelitian ini adalah frekuensi gelombang laut $(1 \mathrm{~Hz}, 2 \mathrm{~Hz}$, dan $3 \mathrm{~Hz})$, dan jumlah cantilever piezoelectric $(\mathbf{1}$, 3, dan 5). Dari hasil simulasi didapatkan hasil bahwa semakin banyak cantilever piezoelectric yang digunakan, semakin besar energi listrik yang dihasilkan serta semakin besar frekuensi yang diberikan pada mekanisme, semakin kecil energi bangkitan yang dihasilkan. Sehingga nilai daya bangkitan maksimal yang dihasilkan 4.92E-06 Watt dengan menggunakan 5 cantilever piezoelectric pada frekuensi $1 \mathrm{~Hz}$.
\end{abstract}

Kata Kunci-Frekuensi, energi listrik, cantilever piezoelectric, PLTG-Air tipe pelampung silinder, gelombang air.

\section{PENDAHULUAN}

G ELOMBANG laut merupakan pergerakan naik dan turunnya muka air laut yang membentuk lembah dan bukit. Gelombang akan mempunyai bentuk ideal jika mengikuti gerak sinusoidal. Pemanfaatan energi gelombang laut untuk sumber energi alternative sangat cocok diterapkan di Indonesia, dimana berdasarkan UU No.4/PRP/1960 tentang perairan Indonesia, wilayah Indonesia mencapai 5.193.252 $\mathrm{km}^{2}$ yang terdiri atas $1.890 .754 \mathrm{~km}^{2}$ luas daratan dan $3.302 .498 \mathrm{~km}^{2}$ luas lautan. Dengan kata lain luas lautannya mencapai $2 / 3$ dari keseluruhan luas Indonesia. Inilah yang menjadikan Indonesia berpeluang besar sebagai salah satu negara yang mengembangkan energy harvesting (pemanen energi) dengan memanfaatkan potensi gelombang laut di perairan Indonesia.

Salah satu cara memanfaatkan energi gelombang laut adalah untuk menghasilkan listrik, atau yang biasa disebut pembangkit listrik tenaga gelombang laut (PLTGL). Sudah ada beberapa penelitian yang mengembangkan PLTGL ini. Pada penelitan I Made Susanto, 2015[1] dijelaskan tentang pemanfaatan prinsip GGL induksi yang dilakukan dalam skala laboratorium dengan menggunakan metode pelampung. Besar GGL induksi dipengaruhi oleh tiga faktor yaitu jumlah lilitan, kuat medan magnet, dan kecepatan gerak magnet. Sedangkan untuk sistem pembangkit listrik, yang mempengaruhi besar GGL induksi diantaranya terletak pada bentuk pelampung, panjang lengan, massa pelampung dan cepatnya putaran pada transmisi. Fungsi gaya inputan adalah dengan memanfaatkan gaya angkat dari gelombang dan gaya apung dari pelampung. Sedangkan pada kasus pembangkit listrik tenaga gelombang laut, gaya apung dan gaya angkat dari gelombang laut sangat dipengaruhi oleh massa pelampung dan massa dari batang penggeraknya. Pada saat pergerakan turun secara riilnya dapat dimanfaatkan sebagai penggerak generator dengan memanfaatkan gaya berat batang dan gaya berat pelampung.

Dimana pada penelitian yang sudah dilakukan I Made voltase yang dihasilkan berasal dari putaran generator, pada penelitian ini digunakan cantilever piezoelectric sebagai pengganti generator. Cantilever piezoelectric material merupakan material yang memiliki kemampuan untuk membangkitkan potensial listrik sebagai respon dari tegangan mekanik yang diberikan pada material tersebut. Blade dipasang seporos dengan poros keluaran pada gearbox hingga memukul cantilever piezoelectric hingga menyebabkan cantilever piezoelectric terdefleksi. Defleksi dari cantilever piezoelectric inilah yang menimbulkan energi listrik.

\section{URAIAN PENELITIAN}

Dalam mekanisme PLTG-Air terdapat komponen penting yaitu lengan pengungkit dan pelampung yang dapat menghasilkan kecepatan sudut dan torsi ketika diberikan input berupa energi gelombang air. Desain untuk peletakan mekanisme PLTG-Air dapat dilihat pada gambar 1(a), dimana 
housing dibuat diam sehingga saat pelampung silinder dikenai gaya gelombang maka pelampung akan bergerak naik turun. Besar kecilnya gaya gelombang dipengaruhi oleh amplitudo dan frekuensi gelombang sehingga jarak peletakan mekanisme dari permukaan gelombang tidak mempengaruhi gaya gelombang. Kecepatan sudut dan torsi yang dihasilkan lengan pengungkit diteruskan ke mekanisme gearbox. Rasio putaran gearbox adalah 1:5 [1]. Torsi yang dihasilkan gearbox digunakan untuk memukul cantilever piezoelectric dan menghasilkan energi listrik dalam bentuk voltase. Untuk lebih jelasnya detail mekanisme dapat dilihat pada gambar 1(b)

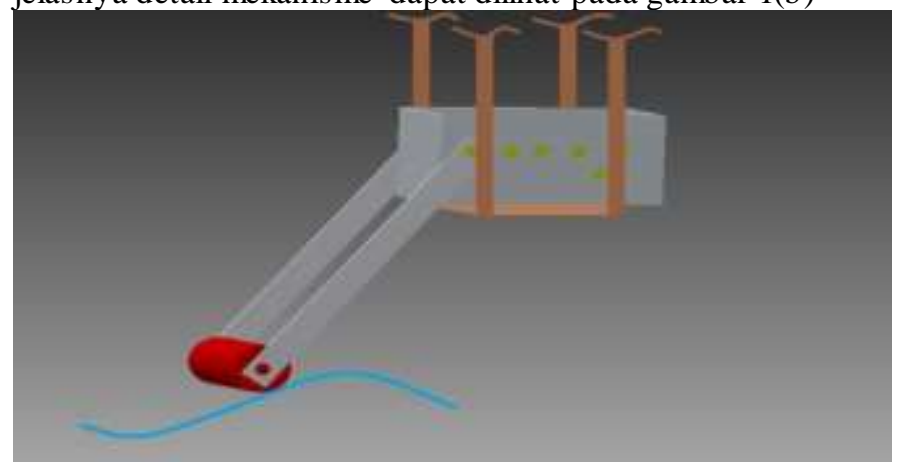

(a)

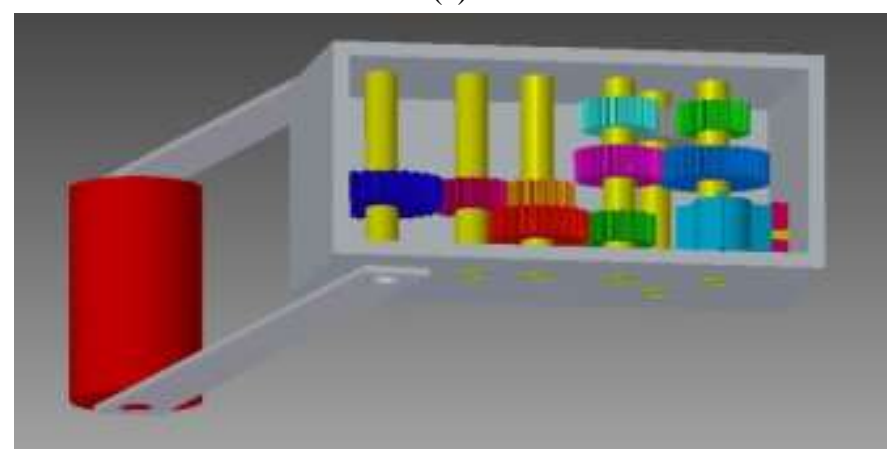

(b)

Gambar 1. Pemodelan (a) peletakan mekanisme PLTG-AIR (b) susunan gearbox mekanisme PLT G-Air.

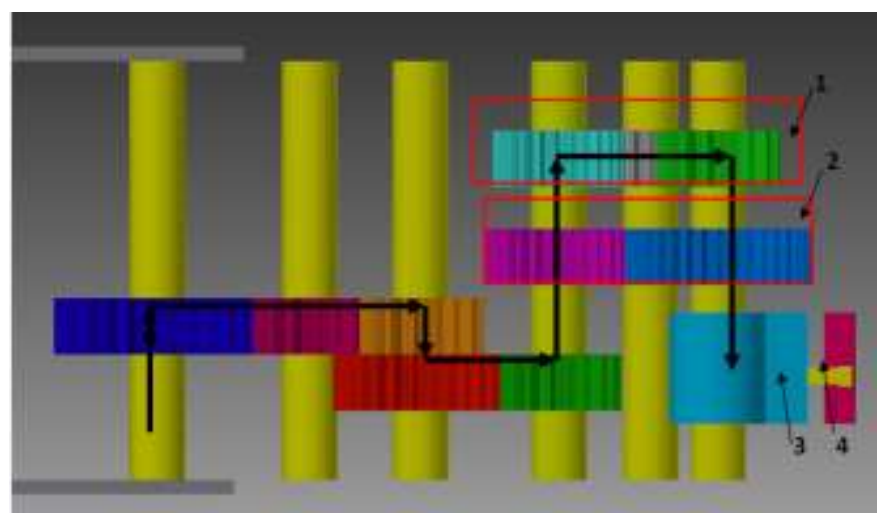

(a)

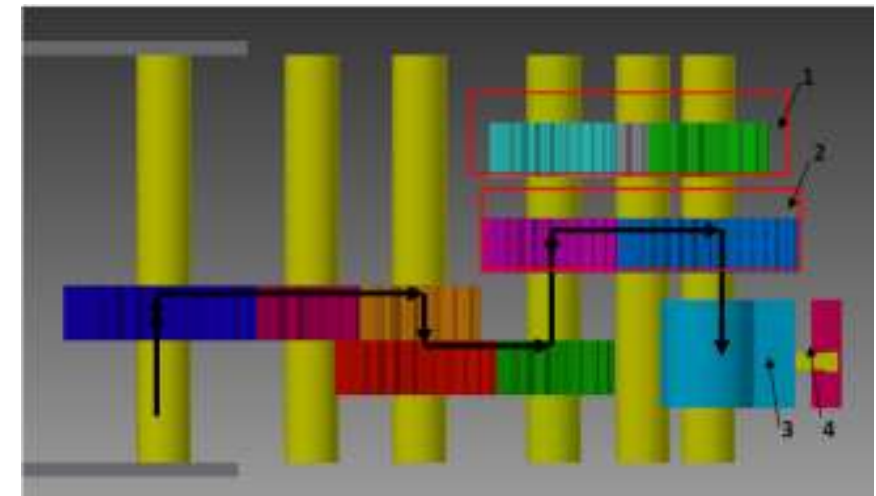

(b)

Gambar.2. Pemodelan (A) mekanisme gearbox saat pelampung bergerak ke bawah (B) mekanisme gearbox saat pelampung bergerak ke atas

Keterangan:

1 = Gearbox pada saat pelampung bergerak turun

2 = Gearbox pada saat pelampung bergerak naik

3 = Blade

4 = Piezoelectric

Prinsip kerja alat pada gambar 2(a) yaitu pada saat lengan bergerak ke bawah akibat berat lengan dan pelampung, gaya diteruskan ke gearbox dan dilanjutkan ke gearbox 1. Torsi hanya bisa lewat pada sistem gearbox 1 sedangkan pada sistem gearbox 2 roda gigi terlepas karena terdapat one way bearing. Putaran sistem gearbox 1 diteruskan ke cantilever piezoelectric melalui blade. Penggunaan mekanisme one way bearing bertujuan untuk mengontrol putaran gearbox pada saat lengan bergerak ke atas maupun ke bawah, sehingga blade tetap berputar pada satu arah dan kontinyu.

Sedangkan untuk mekanisme pada gambar 2(b) adalah saat lengan bergerak ke atas karena pengaruh gelombang air maka gaya yang dihasilkan oleh lengan dilanjutkan ke gearbox dan diteruskan ke gearbox 2. Torsi hanya bisa lewat ke sistem gearbox 2, sedangkan pada sistem gearbox 1 netral karena dipasang sebuah one way bearing. Dari sistem gearbox 2 diteruskan ke cantilever piezoelectric melalui blade. Blade berputar dengan kecepatan sudut lima kali lebih besar dari kecepatan sudut putaran roda gigi input.

$>$ Persamaan Matematis Kesetimbangan Dinamis Pada Lengan Dan Pelampung

$J_{0} \ddot{\theta}_{0}+\left(W p . l+W b \cdot \frac{l}{2}\right) \theta+k_{0}\left(\theta_{0}-\theta_{1}\right)-F_{w} . l=0 \ldots$

Persamaan Matematis Jeq Saat Pelampung Turun

$J_{e q} \ddot{\theta}_{B 1}-k_{0}\left(\theta_{0}-\theta_{B 1}\right)+F_{C B P 1} r_{B}=0$

Persamaan Matematis Jeq Saat Pelampung Naik

$J_{e q} \ddot{\theta}_{B 2}-k_{0}\left(\theta_{0}-\theta_{B 2}\right)+F_{C B P 2} r_{B}=0$

> Persamaan Matematis Untuk Massa Piezoelectric

$M_{p} \cdot \ddot{x}_{p}+K_{p} \cdot x_{p}+F e=F_{\text {impact }}$

> Persamaan Electrik Cantilever Piezoelectric

$V_{m c}=L_{m c} \cdot \frac{d I_{m c}}{d t}+R_{m c} \cdot I_{m c}+\frac{1}{C_{m c}} \int I_{m c} d t+V_{p}$ 


\section{HASIL DAN ANALISA}

Persamaan gerak yang didapatkan dari pemodelan matemati diterjemahkan pada block simulink, dengan inputan yang digunakan berupa gaya gelombang air yang divariaskan pada frekuensi. Pemodelan ini ditujukan untuk mengetahui besarnya energi yang dihasilkan mekanisme.

\section{A. Pemodelan Pada Simulink Matlab}

a. Pemodelan Gaya Gelombang Air

Pada gambar 3 menunjukkan grafik pergerakan gelombang air yang digunakan sebagai gaya inputan dari mekanisme. Variasi yang digunakan adalah variasi frekuensi, yaitu $1 \mathrm{~Hz}$, $2 \mathrm{~Hz}$ dan $3 \mathrm{~Hz}$. Tinggi gelombang yang digunakan adalah $0.04 \mathrm{~m}$.

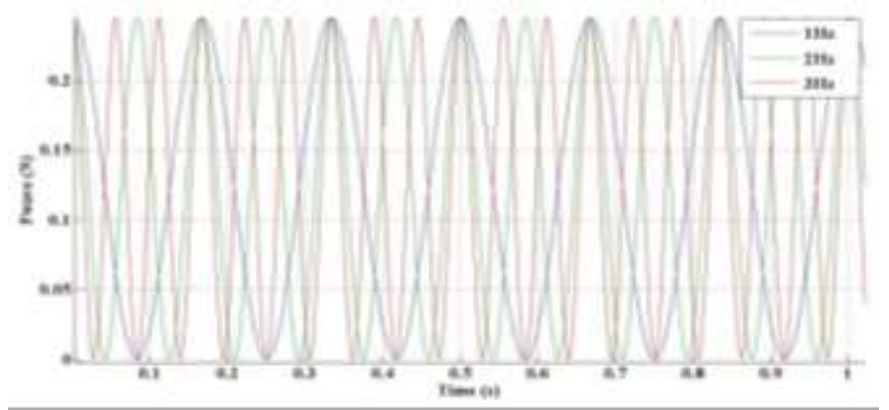

Gambar 3. Grafik pergerakan gelombang air menggunakan satu buah cantilever piezoelectric dengan variasi frekuensi

b. Displacement Cantilever Piezoelectric dengan Variasi Frekuensi dan Jumlah Cantilever Piezoelectric

Pada gambar 4 dapat dilihat grafik displacement pada saat frekuensi $1 \mathrm{~Hz}$ dengan variasi jumlah cantilever piezoelectric sebanyak 1, 3, dan 5 buah. Pada saat dipasang 1, 3 dan 5 cantilever piezoelectric didapatkan nilai displacement terbesar secara berurutan sebesar $0.0126 \mathrm{~m}, 0.004033 \mathrm{~m}$, dan $0.002632 \mathrm{~m}$. Sistem mencapai titik stabil pada waktu $1.655 \mathrm{~s}$. Diantara ketiga variasi tersebut diketahui bahwa displacement terbesar terjadi saat menggunakan 1 cantilever piezoelectric. Untuk grafik displacement dengan input frekuensi sebesar 2 $\mathrm{Hz}$ dan $3 \mathrm{~Hz}$ memiliki grafik seperti pada gambar4.

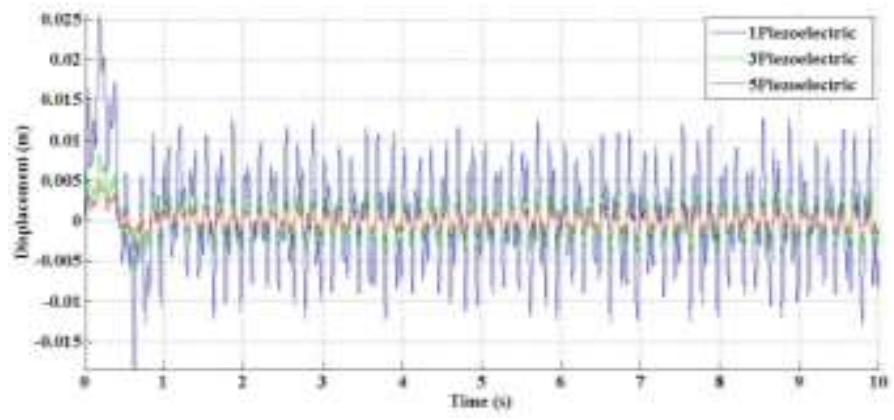

Gambar 4. Grafik Displacement Cantiever Piezoelectric Frekuensi 1Hz Terhadap Waktu Dengan Variasi Jumlah Cantiever Piezoelectric

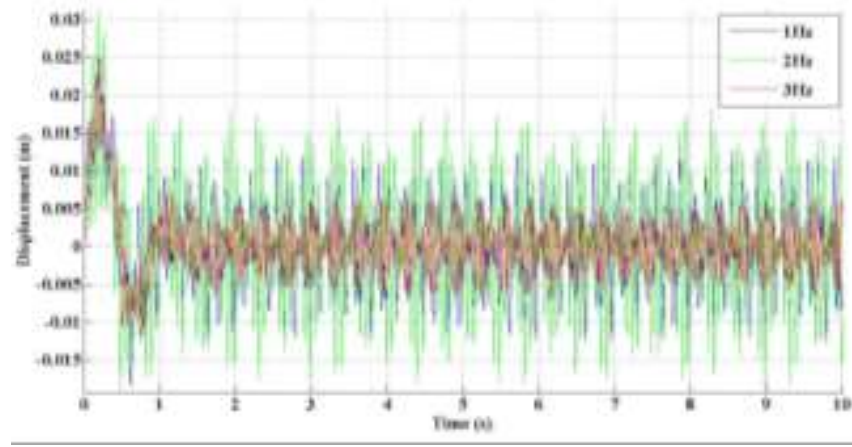

Gambar 5. Grafik Displacement Satu Buah Cantiever Piezoelectric Terhadap Waktu Dengan Variasi Frekuensi

Pada gambar 5 dapat dilihat grafik displacement satu buah cantilever piezoelectric terhadap waktu dengan variasi frekuensi sebesar $1 \mathrm{~Hz}, 2 \mathrm{~Hz}$ dan $3 \mathrm{~Hz}$. Nilai displacement tertingggi saat frekuensi $1 \mathrm{~Hz}, 2 \mathrm{~Hz}$ da $3 \mathrm{~Hz}$ adalah $0.01286 \mathrm{~m}$, $0.01866 \mathrm{~m}$ dan $0.006599 \mathrm{~m}$. Sistem mencapai titik stabil pada waktu 0.8348s. Pada grafik dapat diketahui displacement tertinggi terjadi saat input frekuensi sebesar $2 \mathrm{~Hz}$. Untuk variasi jumlah cantilever piezoelectric sebanyak 3 dan 5 buah, hasil grafik yang didapatkan serupa dengan grafik pada gambar 5.

c. Voltase Bangkitan Cantilever Piezoelectric dengan Variasi Frekuensi dan Jumlah Cantilever Piezoelectric

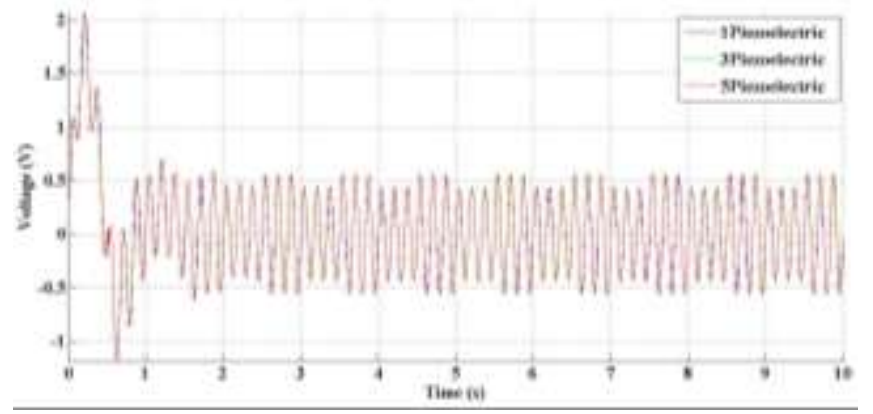

Gambar 6. Grafik Voltase Cantiever Piezoelectric Frekuensi 1Hz Terhadap Waktu Dengan Variasi Jumlah Cantiever Piezoelectric

Gambar 6 menunjukkan grafik voltase saat input frekuensi sebesar $1 \mathrm{~Hz}$. Grafik yang dihasilkan saat menggunakan 1, 3 dan 5 buah cantilever piezoelectric memiliki garis yang hampir sama. Nilai tertinggi dari grafik yang dihasilkan saat dipasang cantilever piezoelectric sebanyak 1,3 dan 5 adalah $0.5649 \mathrm{~V}, 0.5682$ dan $0.5658 \mathrm{~V}$. Sistem stabil pada waktu 1.499s. Untuk grafik arus dengan input frekuensi sebesar $2 \mathrm{~Hz}$ dan $3 \mathrm{~Hz}$ memiliki grafik seperti pada gambar 6 .

Pada gambar 7 menunjukkan grafik voltase yang dihasilkan dari satu buah cantilever piezoelectric dengan variasi frekuensi. Pada saat frekuensi $1 \mathrm{~Hz}, 2 \mathrm{~Hz}$ dan $3 \mathrm{~Hz}$ nilai voltase terbesar $0.5682 \mathrm{~V}, 0.2792 \mathrm{~V}$ dan $0.1842 \mathrm{~V}$. Sistem stabil pada waktu $1.5 \mathrm{~s}$. Dari ketiga variasi frekuensi tersebut nilai voltase terbesar terjadi saat frekuensi $1 \mathrm{~Hz}$. Grafik voltase bangkitan yang dihasilkan dari 3 dan 5 buah cantilever piezoelectric memiliki bentuk yang serupa dengan grafik pada gambar 7 . 


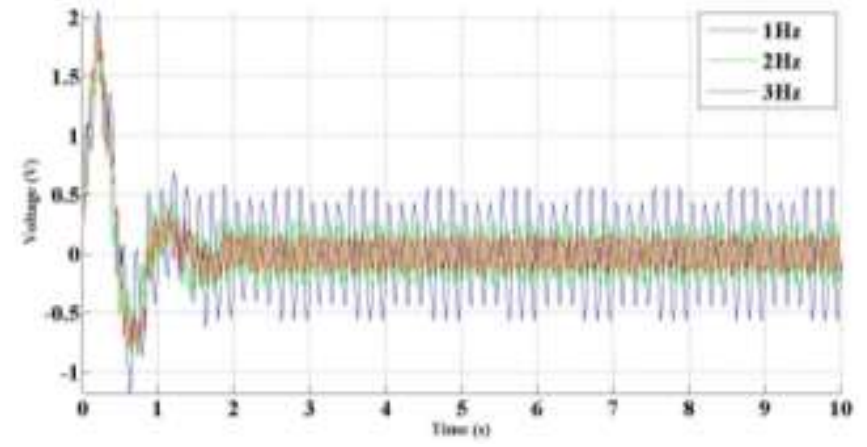

Gambar 7. Grafik Voltase Satu Buah Cantilever Piezoelectric Dengan Variasi Frekuensi

d. Arus Bangkitan Cantilever Piezoelectric dengan Variasi Frekuensi dan Jumlah Cantilever Piezoelectric

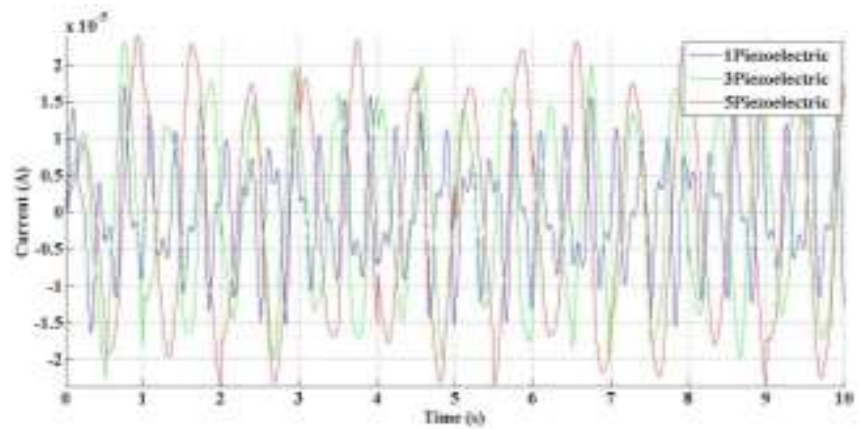

Gambar 8. Grafik Arus Cantiever Piezoelectric Frekuensi 1Hz Terhadap Waktu Dengan Variasi Jumlah Cantiever Piezoelectric

Pada gambar 8 dapat dilihat grafik arus yang dihasilkan pada saat diberikan input frekuensi sebesar $1 \mathrm{~Hz}$. Pada saat menggunakan 1, 3 dan 5 buah cantilever piezoelectric didapatkan nilai arus terbesar adalah 1.719E-05A, 2.309E-05A dan 2.388E-05A. Sehingga nilai arus terbesar terjadi saat menggunakan 5 cantilever piezoelectric dan sistem stabil setelah mencapai waktu $0.5954 \mathrm{~s}$. Untuk grafik arus dengan input frekuensi sebesar $2 \mathrm{~Hz}$ dan $3 \mathrm{~Hz}$ memiliki grafik seperti pada gambar 8 .

Gambar 9 menunjukkan grafik arus yang dihasilkan satu buah cantilever piezoelectric. Arus yang dihasilkan dipengaruhi oleh adanya variasi frekuensi yang digunakan. Dimana secara berturut-turut didapatkan nilai arus terbesar pada frekuensi $1 \mathrm{~Hz}, 2 \mathrm{~Hz}$ dan $3 \mathrm{~Hz}$ adalah $1.719 \mathrm{E}-05 \mathrm{~A}$, 1.803E-05A dan 1.612E-05A. Pada waktu 0.3892s sistem mulai stabil. Dari data tersebut nilai arus terbesar terjadi pada frekuensi $2 \mathrm{~Hz}$. Untuk grafik arus dengan 3 dan 5 cantilever piezoelectric memiliki bentuk grafik seperti pada gambar 9 .

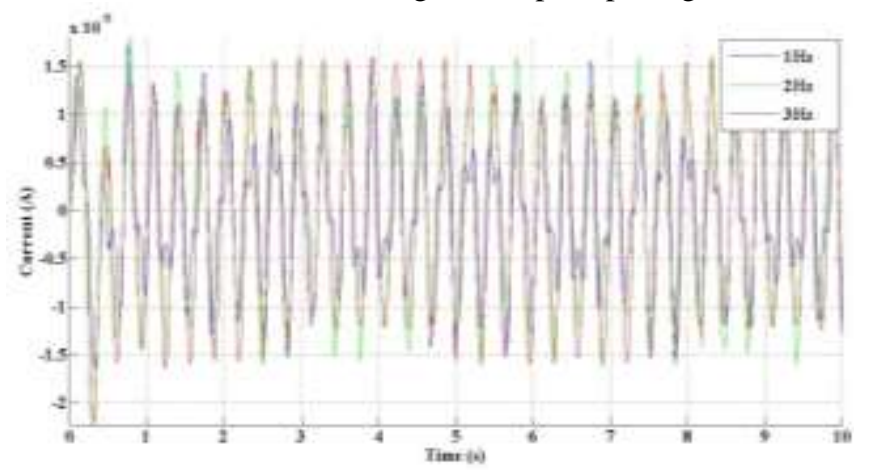

Gambar 9. Grafik Arus Satu Buah Cantilever Piezoelectric Dengan Variasi Frekuensi e. Daya Bangkitan Cantilever Piezoelectric Dengan Variasi Frekuensi Dan Jumlah Cantilever Piezoelectric

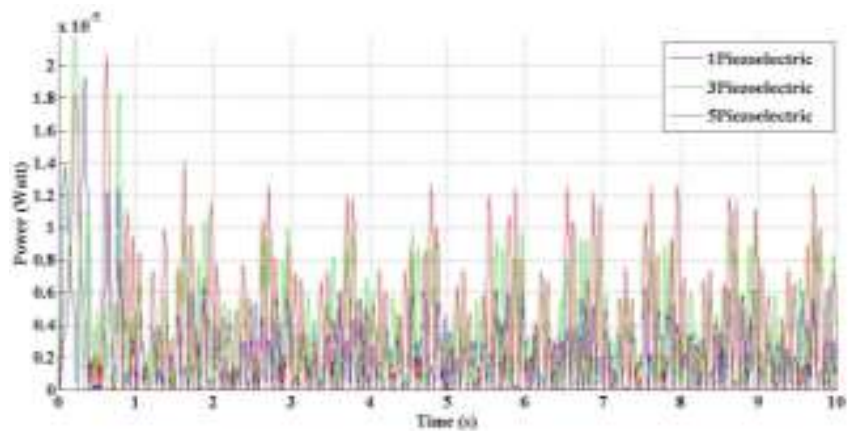

Gambar 10. Grafik Daya Cantiever Piezoelectric Frekuensi 1Hz Terhadap Waktu Dengan Variasi Jumlah Cantiever Piezoelectric

Gambar 10 menunjukkan grafik daya dengan input frekuensi sebesar $1 \mathrm{~Hz}$. Pada saat menggunakan 1, 3 dan 5 buah cantilever piezoelectric, nilai daya terbesar adalah 6.301E-06Watt, 1.047E-05Watt dan 1.417E-05Watt. Pada waktu $0.8371 \mathrm{~s}$ sistem mulai stabil. Dari grafik tersebut diketahui daya terbesar dihasilkan saat menggunakan 5 cantilever piezoelectric. Untuk grafik daya dengan input frekuensi sebesar $2 \mathrm{~Hz}$ dan $3 \mathrm{~Hz}$ memiliki grafik seperti pada gambar 10.

Pada gambar 11 menunjukkan grafik daya yang dihasilkan oleh satu buah cantilever piezoelectric dengan variasi frekuensi. Didapatkan nilai daya terbesar saat diberikan input frekuensi $1 \mathrm{~Hz}, 2 \mathrm{~Hz}$ dan $3 \mathrm{HZ}$ adalah $6.372 \mathrm{E}-06 \mathrm{~W}$ att, 4.13E06W att dan 2.757E-06Watt. Sehingga daya terbesar saat input $1 \mathrm{~Hz}$. Sistem stabil pada saat $1.675 \mathrm{~s}$. Grafik arus dengan jumlah cantilever piezoelectric 3 dan 5 buah memiliki bentuk grafik seperti pada gambar 11 .

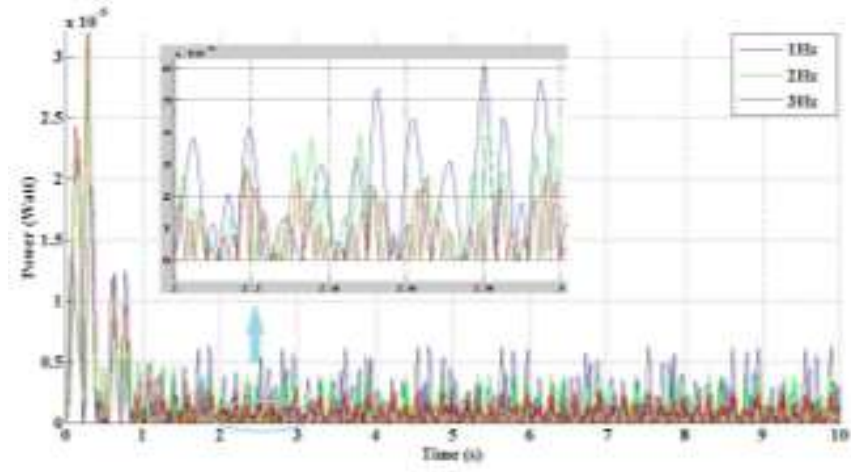

Gambar 11. Grafik Daya Satu Buah Cantilever Piezoelectric Dengan Variasi Frekuensi

Pada gambar 10 dan 11, grafik mencapai stabil dan membentuk grafik sinusoidal setelah detik ke $0.8371 \mathrm{~s}$ dan 1.675 s. Bentuk grafik pada 0s sampai ke kedua detik tersebut terjadi akibat nilai inputan yang diberikan gaya gelombang (Fwave) bernilai positif sehingga untuk mencapai stabil atau kondisi sinus oidal dibutuhkan waktu.

Dari hasil analisis tersebut dapat dilihat pada tabel 1 data mengenai energi bangkitan dengan variasi frekuensi dan jumlah cantilever piezoelectric..

Tabel 1.

Data Energi Bangkitan Dengan Variasi Frekuensi Dan Jumlah Cantilever Piezoelectric 


\begin{tabular}{ccccc}
\hline \hline FREKUENSI & $\begin{array}{c}\text { JUMLAH } \\
\text { PIEZOELECTRIC }\end{array}$ & $\begin{array}{c}\text { VOLTASE } \\
\text { (V) }\end{array}$ & ARUS (A) & $\begin{array}{c}\text { DAYA } \\
\text { (Watt) }\end{array}$ \\
\hline \multirow{3}{*}{1} & 1 & 0.3774 & $7.18 \mathrm{E}-06$ & $2.61 \mathrm{E}-06$ \\
& 3 & 0.3752 & $1.13 \mathrm{E}-05$ & $4.06 \mathrm{E}-06$ \\
& 5 & 0.3731 & $1.39 \mathrm{E}-05$ & $4.92 \mathrm{E}-06$ \\
2 & 1 & 0.2246 & $9.25 \mathrm{E}-06$ & $2.42 \mathrm{E}-06$ \\
& 3 & 0.2238 & $1.22 \mathrm{E}-05$ & $2.43 \mathrm{E}-06$ \\
& 5 & 0.2220 & $1.47 \mathrm{E}-05$ & $2.69 \mathrm{E}-06$ \\
3 & 1 & 0.1929 & $9.77 \mathrm{E}-06$ & $2.24 \mathrm{E}-06$ \\
& 3 & 0.1891 & $1.25 \mathrm{E}-05$ & $2.34 \mathrm{E}-06$ \\
& 5 & 0.1871 & $1.48 \mathrm{E}-05$ & $2.45 \mathrm{E}-06$ \\
\hline \hline
\end{tabular}

B. Pembahasan

a. Pengaruh Frekuensi dan Jumlah Piezoelectric Terhadap Voltase Bangkitan Piezoelectric

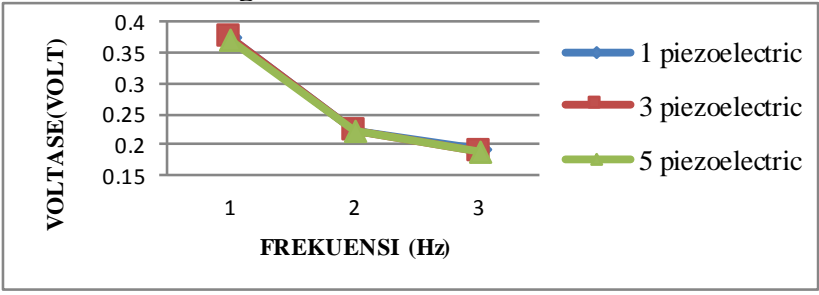

Gambar 12. Grafik pengaruh frekuensi gelombang air terhadap voltase bangkitan dari masing - masing jumlah cantilever piezoelectric.

Pada gambar 12 menunjukkan grafik pengaruh frekuensi gelombang air terhadap voltase bangkitan yang dihasilkan dengan variasi jumlah cantilever piezoelectric. Terdapat tiga buah grafik yang mewakili tiga variasi jumlah cantilever piezoelectric yaitu 1, 3, dan 5 buah cantilever piezoelectric. Nilai RMS voltase untuk 1 buah cantilever piezoelectric pada saat frekuensi $1 \mathrm{~Hz}, 2 \mathrm{~Hz}$, dan $3 \mathrm{~Hz}$ adalah $0.3774 \mathrm{~V}, 0.2246 \mathrm{~V}$, dan $0.1929 \mathrm{~V}$, nilai RMS voltase untuk 3 buah cantilever piezoelectric pada saat frekuensi $1 \mathrm{~Hz}, 2 \mathrm{~Hz}$, dan $3 \mathrm{~Hz}$ adalah $0.3752 \mathrm{~V}, 0.2238 \mathrm{~V}$, dan $0.1891 \mathrm{~V}$, serta nilai RMS voltase untuk 5 buah cantilever piezoelectric pada saat frekuensi $1 \mathrm{~Hz}$, $2 \mathrm{~Hz}$, dan $3 \mathrm{~Hz}$ adalah $0.3731 \mathrm{~V}, 0.2220 \mathrm{~V}$, dan $0.1871 \mathrm{~V}$. Dari ketiga grafik tersebut dapat dilihat trendine setiap grafik menurun seiring bertambahnya frekuensi gelombang air karena dengan bertambahnya frekuensi gelombang air maka gaya gelombang air juga semakin kecil. Sesuai rumusan dimana frekuensi berbanding terbalik dengan Fwave (gaya gelombang air). Gaya gelombang air berfungsi sebagai inputan, sehingga jika gaya gelombang air semakin kecil maka semakin kecil gaya impact (Fimpact) dari blade yang mengenai cantilever piezoelectric. Sehingga, semakin kecil gaya impact maka displacement pada cantilever piezoelectric semakin kecil pula. Displacement inilah yang mempengaruhi besarnya voltase yang dihasilkan.

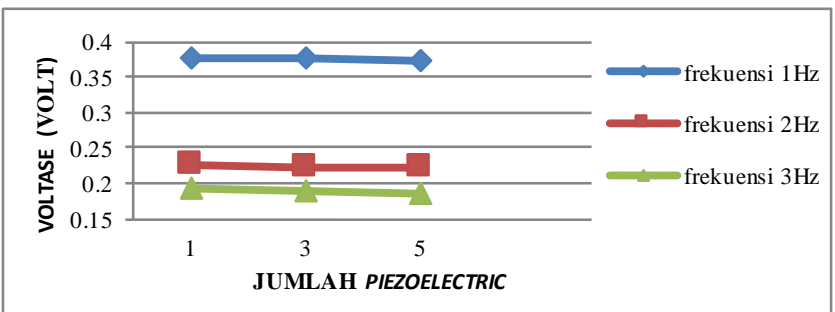

Gambar 13. Grafik pengaruh jumlah cantilever piezoelectric terhadap volt ase bangkitan dari masing - masing frekuensi gelombang air.

Pada gambar 13 menunjukkan grafik pengaruh jumlah cantilever piezoelectric terhadap voltase bangkitan dari masing - masing frekuensi gelombang air yang dihasilkan dari mekasisme PLTG-Air. Terdapat tiga buah grafik yang mewakili tiga variasi frekuensi gelombang air yaitu $1 \mathrm{~Hz}$, $2 \mathrm{~Hz}$,dan 3Hz. Trendine setiap grafik cenderung tetap meskipun ada sedikit penurunan seiiring bertambahnya jumlah cantilever piezoelectric karena semakin bertambah jumlah cantilever piezoelectric maka gaya impact yang digunakan untuk menggerakkan cantilever piezoelectric semakin kecil. Semakin kecil gaya impact semakin kecil pula voltase yang dihasilkan. Untuk sistem rangkaian elektris, cantilever piezoelectric disusun secara paralel. Penyusunan secara paralel ini membuat nilai voltase bangkitan cantilever piezoelectric tetap pada masing - masing cantilever piezoelectric. Cantilever piezoelectric dianggap seperti sumber energi (baterai) yang dilalui arus listrik sehingga ketika rangkaian disusun secara paralel maka besarnya voltase akan tetap meskipun dengan penambahan jumlah cantilever piezoelectric.

b. Pengaruh Frekuensi dan Jumlah Piezoelectric Terhadap Arus Bangkitan Piezoelectric

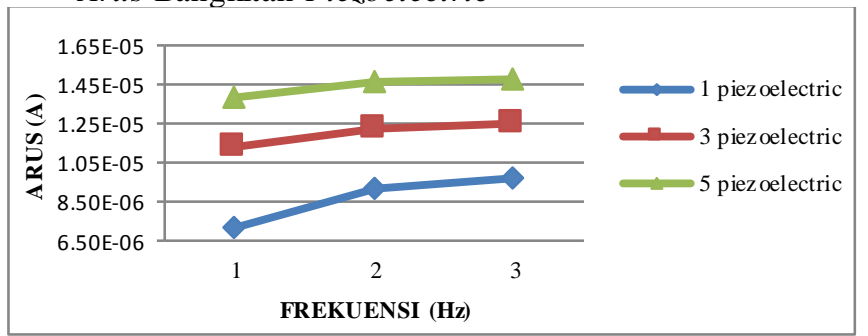

Gambar 14. Grafik pengaruh frekuensi gelombang air terhadap arus listrik bangkitan dari masing - masing jumlah cantilever piezoelectric.

Pada gambar 14 menunjukkan grafik pengaruh frekuensi gelombang air terhadap arus listrik bangkitan yang dihasilkan dari mekasisme PLTG-Air dengan variasi jumlah cantilever piezoelectric. Terdapat tiga buah grafik yang mewakili tiga variasi jumlah cantilever piezoelectric yaitu 1, 3, dan 5 buah. Dapat dilihat nilai RMS arus untuk 1 buah cantilever piezoelectric pada saat frekuensi $1 \mathrm{~Hz}, 2 \mathrm{~Hz}$, dan $3 \mathrm{~Hz}$ adalah 7.18E-06A, 9.25E-06A dan 9.77E-06A, nilai RMS arus untuk 3 buah cantilever piezoelectric pada saat frekuensi $1 \mathrm{~Hz}, 2 \mathrm{~Hz}$, dan $3 \mathrm{~Hz}$ adalah 1.13E-05A, 1.22E-05A, dan 1.25E-05A, serta nilai RMS arus untuk 5 buah cantilever piezoelectric pada saat frekuensi $1 \mathrm{~Hz}, 2 \mathrm{~Hz}$, dan $3 \mathrm{~Hz}$ adalah $1.39 \mathrm{E}-05 \mathrm{~A}, 1.47 \mathrm{E}-05 \mathrm{~A}$, dan 1.48E-05A. Dari ketiga grafik tersebut dapat dilihat trendine setiap grafik meningkat seiring bertambahnya frekuensi gelombang air karena semakin besar frekuensi gelombang air, maka semakin mendekati frekuensi natural dari cantilever piezoelectric. Sehingga semakin besar frekuensi gelombang air, semakin besar pula kecepatan pergerakan cantilever piezoelectric dan semakin besar pula arus bangkitan yang dihasilkan. Berdasarkan uraian tersebut maka dapat ditarik kesimpulan bahwa semakin besar frekuensi gelombang air yang diberikan maka semakin besar arus yang 
dihasilkan.

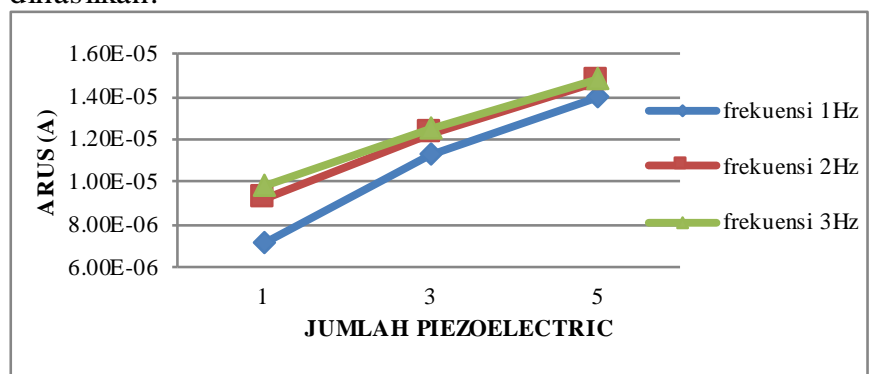

Gambar 15. Grafik pengaruh jumlah cantilever piezoelectric terhadap arus listrik bangkitan dari masing - masing frekuensi gelombang air

Pada 15 menunjukkan grafik pengaruh jumlah cantilever piezoelectric terhadap arus listrik bangkitan dari masing masing frekuensi gelombang air. Terdapat tiga buah grafik yang mewakili tiga variasi frekuensi gelombang air yaitu $1 \mathrm{~Hz}$, $2 \mathrm{~Hz}$,dan $3 \mathrm{~Hz}$. Dari ketiga grafik tersebut dapat dilihat trendine setiap grafik naik seiiring bertambahnya jumlah cantilever piezoelectric karena pada rangkaian elektris ini cantilever piezoelectric disusun secara paralel. Penyusunan cantilever piezoelectric secara paralel menyebabkan semakin banyak jumlah cantilever piezoelectric maka semakin banyak pula faktor pengkali pada nilai arus bangkitan per satu cantilever piezoelectric.

c. Pengaruh Frekuensi dan Jumlah Piezoelectric Terhadap daya Bangkitan Piezoelectric

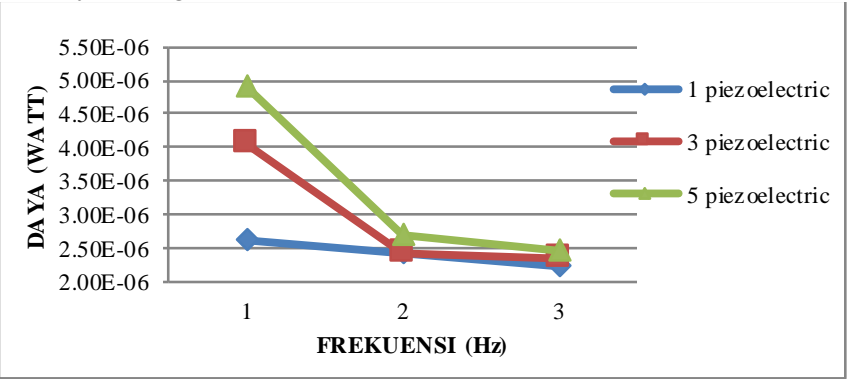

Gambar 16. Grafik pengaruh frekuensi gelombang air terhadap daya listrik bangkitan dari masing - masing jumlah cantilever piezoelectric.

Pada gambar 16 menunjukkan grafik pengaruh frekuensi gelombang air terhadap daya listrik bangkitan yang dihasilkan dari mekasisme PLTG-Air dengan variasi jumlah cantilever piezoelectric. Terdapat tiga buah grafik yang mewakili tiga variasi jumlah cantilever piezoelectric yaitu 1, 3, dan 5 buah. Dapat dilihat nilai RMS daya untuk 1 buah cantilever piezoelectric pada saat frekuensi $1 \mathrm{~Hz}, 2 \mathrm{~Hz}$, dan $3 \mathrm{~Hz}$ adalah 2.61E-06Watt, 2.42E-06Watt dan 2.24E-06Watt, nilai RMS daya untuk 3 buah cantilever piezoelectric pada saat frekuensi $1 \mathrm{~Hz}, 2 \mathrm{~Hz}$, dan $3 \mathrm{~Hz}$ adalah 4.06E-06W att, 2.43E-06Watt, dan 2.34E-06Watt, serta nilai RMS daya untuk 5 buah cantilever piezoelectric pada saat frekuensi $1 \mathrm{~Hz}, 2 \mathrm{~Hz}$, dan $3 \mathrm{~Hz}$ adalah 4.92E-06W att, 2.69E-06W att, dan 2.45E-06Watt. Dari ketiga grafik tersebut dapat dilihat trendine setiap grafik menurun dengan bertambahnya frekuensi dikarenakan dipengaruhi oleh nilai arus dan voltase yang dihasilkan dari mekanisme PLTGAir. Sesuai rumusan, dimana daya merupakan hasil kali voltase dengan arus. Dimana voltase menurun dengan bertambahnya frekuensi. Inilah yang menjadikan trendline daya mengalami penurunan.

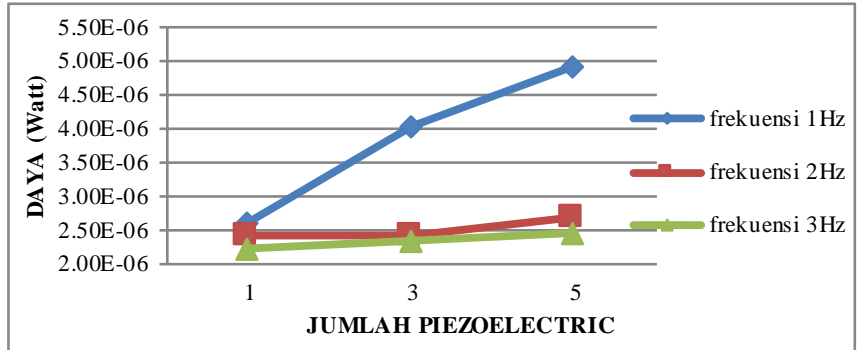

Gambar 17. Grafik pengaruh jumlah cantilever piezoelectric terhadap daya listrik bangkitan dari masing - masing frekuensi gelombang air.

Pada gambar 17 menunjukkan grafik pengaruh jumlah cantilever piezoelectric terhadap daya listrik bangkitan dari masing - masing frekuensi gelombang air. Terdapat tiga buah grafik yang mewakili tiga variasi frekuensi gelombang air yaitu $1 \mathrm{~Hz}, 2 \mathrm{~Hz}$,dan $3 \mathrm{~Hz}$. Dari ketiga grafik tersebut dapat dilihat trendine setiap grafik naik seiiring bertambahnya jumlah cantilever piezoelectricdikarenakan seiring bertambahnya jumlah cantilever piezoelectric maka daya yang dihasilkan juga semakin besar. Hal ini dikarenakan dengan bertambahnya jumlah cantilever piezoelectric yang dipasang secara paralel maka bertambah pula nilai arus setiap bertambahnya jumlah cantilever piezoelectric dengan nilai voltase yang cenderung tetap. Sesuai dengan rumusan bahwa daya merupakan hasil kali arus dengan voltase, sehingga nilai daya berbanding lurus dengan nilai arus. Jika nilai daya semakin besar maka nila arus juga akan semakin besar, dan sebaliknya. Berdasarkan uraian tersebut dapat disimpulkan bahwa nilai daya meningkat seiring dengan bertambahnya jumlah cantilever piezoelectric.

\section{KESIMPULAN}

Dari hasil analisa dan pembahasan yang telah dilakukan, dapat diambil kesimpulan:

1. Jumlah cantilever piezoelectric berpengaruh terhadap energi bangkitan yang dihasilkan. Semakin banyak cantilever piezoelectric yang digunakan, semakin besar pula energi listrik yang dihasilkan. Dengan jumlah cantilever piezoelectric sebanyak 5 buah didapatkan nilai daya bangkitan terbesar saat frekuensi $1 \mathrm{~Hz}$ adalah $4.92 \mathrm{E}-$ 06W att, saat frekuensi $2 \mathrm{~Hz}$ adalah 2.69E-06 Watt, dan saat frekuensi $3 \mathrm{~Hz}$ adalah 2.45E-06Watt dengan jumlah cantilever piezoelectric sebanyak 5 buah.

2. Frekuensi berpengaruh terhadap energi bangkitan yang dihasilkan. Semakin besar frekuensi yang diberikan pada mekanisme PLTG-Air, semakin kecil energi bangkitan yang dihasilkan. Sehingga nilai daya terbesar terjadi saat frekuensi $1 \mathrm{~Hz}$ dengan jumlah cantilever piezoelectric 1 buah adalah 2.61E-06 Watt, jumlah cantilever piezoelectric 3 buah adalah 4.06E-06 Watt dan saat jumlah cantilever piezoelectric 5 buah adalah $4.92 \mathrm{E}-06$ Watt.

3. Daya listrik bangkitan terbesar yang dapatu dihasilkan oleh pemodelan mekanisme PLTG-Air tipe pelampung silinder dengan 3 variasi frekuensi gelombang laut $(1 \mathrm{~Hz}, 2 \mathrm{~Hz}, 3$ $\mathrm{Hz})$ dan 3 variasi jumlah cantilever piezoelectric $(1,3,5)$ terjadi ketika pemodelan mekanisme dikenakan frekuensi 
gelombang $1 \mathrm{~Hz}$ dengan menggunakan 5 buah cantilever piezoelectric, yaitu dengan nilai daya 4.92E-06 Watt.

\section{UCAPAN TERIMA KASIH}

Penulis mengucapakan terima kasih kepada Dr. Wiwiek Hendrowati ST, MT yang telah membantu penulis dalam melakukan penelitian ini.

\section{DAFTAR PUSTAKA}

[1] Susanto, I Made, 2015. "Studi Karakteristik Energi Listrik Yang Dihasilkan Pembangkit Listrik Tenaga Gelombang Laut (PLTGL) Metode Pelampung Dengan Variasi Dimensi Pelampung Dan Panjang Lengan”. Tugas Akhir pada Jurusan Teknik Mesin: IT S Press. 